\title{
Using of maple syrup as an alternative to sucrose and whey in making healthy functional sherbet-ice
}

\author{
*Mohammed, O.J. and Mahmood, Sh.J. \\ Food Science Department, College of Agriculture, University of Mosul ,Mosul, Iraq
}

Article history:
Received: 31 March 2021
Received in revised form: 18
April 2021
Accepted: 22 June 2021
Available Online: 20
February 2022
Keywords:
Maple syrup,
Sherbet-ice,
Sucrose,
Whey protein
DOI:
https://doi.org/10.26656/fr.2017.6(1).228

\begin{abstract}
The study was aimed to produce refreshing and healthy fat-free, low-calorie drinks by using acid whey as a basic material resulting from making cheese as an alternative to milk. Sugar has been replaced partially or completely with maple syrup at 0, 35, 70 and 100\% and the chemical and physical tests of both blends were conducted. The level results showed a significant decrease in total solids, total sugars, viscosity, overrun, an increase in specific weight, and ash. The control treatment showed higher melting resistance than the rest of the treatments made with the replacement of sugar. Although the total acidity was lower than the comparison sample, the acidity of the maple syrup mixtures was observed to have significantly increased. The fat percentage was not affected by the addition of maple syrup and was not significant. Sensory evaluation showed that the $100 \%$ maple syrup sample received the highest sensory rating score.
\end{abstract}

\section{Introduction}

Large amounts of liquid waste, known as "cheese whey," are produced by food processing industries such as dairy and cheese processing plants (Mollea et al., 2013). Whey is an acidic by-product produced during the manufacture of a range of dairy products, including yoghurts, fresh and soft cheeses such as cream cheeses (Wherry et al., 2019). Whey is the liquid leftover after fat and casein have been removed from milk, and it contains mainly soluble components such as lactose, soluble salts, and globular proteins (Chandrapala et al., 2016). Lactose, on the other hand, is the most abundant portion of whey (approximately $70 \%$ dry matter basis). After cheesemaking, the bulk of milk carbohydrates migrates through the whey, with lactose responsible for $90 \%$ of the amount, along with some glucose, galactose, oligosaccharides, and amino sugars (Božanić et al., 2014). the European Union has the world's biggest cheese market, resulting in a significant supply of acid whey. The production of acid whey from cheese alone is projected to be 40 million tonnes a year in the European Union (Zotta et al., 2020). Whey has many functions of glutamate and emulsification compared to other proteins (Doultani et al., 2003). Whey's toxic consequences are the greatest problem.

Biochemical requirements for oxygen (BOD) are between 40,000 and $60,000 \mathrm{mg} / \mathrm{L}$ and chemical oxygen (COD) between 50,000 and $80000 \mathrm{mg} / \mathrm{L}$ (Chatzipaschali and Sattamis, 2012). Acid whey is distinguished by a high concentration of lactic acid and minerals, which makes industrial production impossible and restricts its food applications. Membrane approaches are used to solve these problems because the structure and properties of raw materials are easily manipulated. Demineralization of acid whey allows removing a significant part of mineral $(50 \%)$ from it and providing the required acidity in the range, corresponding to raw milk (Evdokimov et al., 2015). Whey protein helps promote weight loss, lower cholesterol, and lower blood pressure as a protein supplement, especially for people trying to develop muscles by exercising and eating whey protein powder (Patel, 2015).

In a study conducted, the water in the preparation of Egyptian Baladi, bread was replaced with sweet whey, as the whey improved the physical, chemical, and sensory properties of the bread, and the properties of the bread improved by increasing the substitution rate (Gaber et al., 2017). In the study on the effects of replacing the skim milk with some dried fruit used in making ice cream, there was an increase in the total solids content, $\mathrm{pH}$, specific weight, and viscosity of the resulting ice cream compared to the control sample (Hasan et al., 2020). In a study, whey was prepared as a frozen dessert using pineapple fruit, and kiwi, the results attained a higher sensory score in colour, appearance, taste, and flavour as the frozen whey candy underwent a consumer 
adaptability study and it was found that $58 \%$, of consumers, rated the candy as excellent (Chavan et al., 2020). Maple syrup is usually made from boiling the maple trees, red maple, and black maple and is a natural sweetener that can be changed into sucrose due to its mineral content and high amount of phenolic compounds with vital activities such as antioxidant, antibacterial, and anti-cancer in addition to its content of calcium, iron and other compounds (Mellado-Mojica et al., 2016).

The sap contains about $97 \%$ water and 3\% solids, the solids are mainly sucrose sugar and small amounts of glucose and fructose. It takes forty litres of sap to produce one litre of maple syrup. The process is time and energy consuming (Aider et al., 2007). Maple syrup is the largest natural product produced and consumed commercially and is obtained entirely from deciduous tree sap. It is produced by thermal evaporation of the colourless water sap collected from the maple species (Perkins and Van den Berg, 2009). Maple syrup is produced by concentrating maple tree sap. The physicalchemical features of maple syrup may be depending on the treatment method, microbial contamination, seasonal and geographical differences, minerals and phenolics in maple syrup may provide additional health benefits due to their vital activities (Nimalaratne et al., 2020). It was found to have a strong effect on prostate and lung cancer cells. Another study showed that maple syrup possesses the ability to inhibit nitric oxide. Inhibition of nitric oxide leads to inhibition of inflammation, which may help in the prevention of cancer (Legault et al., 2010).

The consumption of maple syrup has been shown to produce fewer responses to glucose and human insulin, compared to corn syrup, brown rice syrup, and dextrose, making it a better alternative to refined sugars in our diets (St-Pierre et al., 2014). The objective of this study was to use whey protein as a basic material in the chilled drinking industry as it contains a good proportion of mineral salts, proteins, and dissolved vitamins in the water and the lactose, as well as to reduce wastage of whey protein of wastewater. Thus, reducing the proportion of pollution, of the use of the maple syrup as a sugar substitute, sweetener, and natural colourant to fortify the product, as the source is rich in minerals, including iron, zinc, and manganese, as well as a good source of antioxidants.

\section{Materials and methods}

\subsection{Materials}

Fresh whey was obtained from cheese making and used in sherbet-ice sugar. Whereas citric acid and Carboxy Methyl Cellulose (CMC) were purchased from the local market, while maple syrup was purchased from the international market.

\subsection{Preparation of sherbet-ice}

Iced syrups (Sherbet-ice) made according to Salim (1986) were made with four treatments. Each treatment with an amount of $1 \mathrm{~kg}$ heated whey at $40^{\circ} \mathrm{C}$ and added the estimated amount of sugar of $20 \%$ after mixing it with the stabilizer. The dry materials were gradually added and mixed well to complete the melting with a continuous stirring at a temperature of $73^{\circ} \mathrm{C}$ for $15 \mathrm{~s}$ and cooling and a temperature of $5^{\circ} \mathrm{C}$ for a period ranging from 2-4 hrs. The prescribed proportion of maple syrup was added then froze and whisk for 10-13 mins. $250 \mathrm{~mL}$ plastic containers were then filled and transferred into the freezer for hardening at $-18^{\circ} \mathrm{C}$ until further analysis. Table 1 shows the selected compositions for making sherbet-ice mix formulas and indicated that sugar was replaced by maple syrup at levels control (T), 35\% (T1), $70 \%$ (T2), and $100 \%$ (T3).

Table 1. Formulations of Sherbet-ice mixes.

\begin{tabular}{ccccc}
\hline Ingredients/g & $\mathrm{T}$ & $\mathrm{T} 1$ & $\mathrm{~T} 2$ & $\mathrm{~T} 3$ \\
\hline Whey & 800 & 800 & 800 & 800 \\
Total sugar & 200 & 130 & 60 & --- \\
Maple syrup & ---- & 70 & 140 & 200 \\
CMC & 5 & 5 & 5 & 5 \\
Citric acid & 3 & 3 & 3 & 3 \\
Total & 1008 & 1008 & 1008 & 1008 \\
\hline
\end{tabular}

\subsection{Methods of analysis}

Ash, total protein contents, titratable acidity and $\mathrm{pH}$ were determined according to AOAC (2012). The total sugars of the mixtures were calculated by the method of difference between the components as mentioned by Pearson (1996). The Kerber method was used to quantify the lipid in the mixtures according to Ling (1963). The viscosity was estimated using a US-made MODEL RVDVE (BROOKFIELD) device that works on the principle of converting friction into a viscosity reading. Melting resistance was determined according to Sofjan and Hartel (2004) and overrun was determined according to Laaman (2011).

\subsection{Sensory evaluation}

The sensory evaluation for the resultant sherbet-ice was carried out by 10 staff members of the dairy department, for flavour (50 points), texture (30 points), colour (10 points), and appearance (10 points).

\subsection{Statistical analysis}

Data were analysed according to a factor experiment system using the experiment conducted in C.R.D. The averages were tested by Duncan's multi-range test under a probability level of 0.05 as used the SAS Statistical 
Analysis System program, using the computer to conduct statistical analysis of the data.

\section{Results and discussion}

\subsection{Chemical tests}

Table 2 displays the significant decrease in the total solids significantly $(\mathrm{p}<0.05)$ and acidity when replaced with maple syrup, which was proportional to the rate of substitution. On the other hand, $\mathrm{pH}$ values tended to increase with the addition of maple syrup, results are in harmony with those obtained from Yazdanpanah (2020) when sugar was replaced with maple syrup in ice cream. The data indicated that fat was not significantly affected by the substitution even though there was a slight decrease. These results are in agreement with those obtained from Salama et al. (2016). Whereby, the protein content decreased as the maple syrup content increased because it contains a negligible amount of protein. The highest mean protein score was recorded in the control. Those results are in line with the findings of Rashid and Thakur (2012). The ash content of the mixes with a higher proportion of maple syrup increased significantly $(\mathrm{p}<0.05)$, which is consistent with the findings of Farahat (2011) and Salama et al. (2016), who found that when sugar was replaced with date syrup in ice cream production, the ash content increased significantly $(\mathrm{p}<$ $0.05)$.

\subsection{Rheological properties}

Table 3 shows the rheological properties of various materials as compared to the control, the specific gravity of sherbet ice with substituted sugar was higher. With an increase in the percentage of sugar substitution with maple syrup, these results were in harmony with those reported by Tammam et al. (2014). The viscosity levels decreased slightly $(\mathrm{p}<0.05)$. The drop in viscosity ratios may be attributed to a reduction in total solids in iced beverages that use maple syrup instead of sugar. These observations are consistent with Salama et al. (2016). The overrun decreased as the substitution of maple syrup increased significantly compared with control. This decrease in overrun might happened due to the weak functional properties (whipping and foamability) of maple syrup. It was indicated that as specific gravity increased the overrun decreased (Tammam et al., 2014).

\subsection{Melting resistance}

As seen in Table 4 the decreased melting resistance

Table 2. Effect of maple syrup on some properties of replaced sugar sherbet-ice.

\begin{tabular}{lcccc}
\hline Chemical tests & $\mathrm{T}$ & $\mathrm{T} 1$ & $\mathrm{~T} 2$ & $\mathrm{~T}$ \\
\hline Total solids & $28.14 \pm 0.002^{\mathrm{a}}$ & $25.62 \pm 0.12^{\mathrm{b}}$ & $23.87 \pm 0.85^{\mathrm{c}}$ & $18.65 \pm 0.055^{\mathrm{d}}$ \\
Total sugars & $26.41 \pm 0.171^{\mathrm{a}}$ & $23.84 \pm 0.069^{\mathrm{b}}$ & $21.92 \pm 0.037^{\mathrm{c}}$ & $16.67 \pm 0.059^{\mathrm{d}}$ \\
Fat & $0.57 \pm 0.37^{\mathrm{a}}$ & $0.50 \pm 0.18^{\mathrm{a}}$ & $0.46 \pm 0.17^{\mathrm{a}}$ & $0.43 \pm 0.32^{\mathrm{a}}$ \\
Acidity & $0.53 \pm 0.057^{\mathrm{a}}$ & $0.42 \pm 0.00^{\mathrm{d}}$ & $0.44 \pm 0.037^{\mathrm{c}}$ & $0.46 \pm 0.025^{\mathrm{b}}$ \\
PH & $3.96 \pm 0.01^{\mathrm{c}}$ & $4.7 \pm 0.01^{\mathrm{a}}$ & $4.6 \pm 0.037^{\mathrm{a}}$ & $4.2 \pm 0.025^{\mathrm{b}}$ \\
Protein & $0.59 \pm 0.017^{\mathrm{a}}$ & $0.54 \pm 0.01^{\mathrm{c}}$ & $0.55 \pm 0.011^{\mathrm{bc}}$ & $0.51 \pm 0.022^{\mathrm{d}}$ \\
Ash & $0.58 \pm 0.01^{\mathrm{d}}$ & $0.74 \pm 0.015^{\mathrm{c}}$ & $0.93 \pm 0.037^{\mathrm{b}}$ & $1.06 \pm 0.025^{\mathrm{a}}$ \\
\hline
\end{tabular}

Values are presented as mean $\pm \mathrm{SD}$. Values with different superscript within the same row are significantly different $(\mathrm{P}<0.05)$. $\mathrm{T}$ : control, T1: 35\% sugar was replaced by maple syrup, T2: 70\%sugar was replaced by maple syrup, and T3: 100\% sugar was replaced by maple syrup.

Table 3. Effect of maple syrup on some rheological properties of replaced sugar sherbet-ice.

\begin{tabular}{lcccc}
\hline Rheological properties & $\mathrm{T}$ & $\mathrm{T} 1$ & $\mathrm{~T} 2$ & $\mathrm{~T} 3$ \\
\hline Specific weight & $0.686 \pm 0.001^{\mathrm{c}}$ & $0.784 \pm 0.003^{\mathrm{b}}$ & $0.865 \pm 0.049^{\mathrm{a}}$ & $0.887 \pm 0.06^{\mathrm{a}}$ \\
Viscosity & $674.33 \pm 5.132^{\mathrm{a}}$ & $454.33 \pm 2.309^{\mathrm{b}}$ & $372.66 \pm 2.517^{\mathrm{c}}$ & $322 \pm 1^{\mathrm{d}}$ \\
Over run $^{\mathrm{a}}$ & $54.70 \pm 1.009^{\mathrm{a}}$ & $40.91 \pm 0.395^{\mathrm{b}}$ & $31.48 \pm 0.769^{\mathrm{c}}$ & $23.36 \pm 0.230^{\mathrm{d}}$ \\
\hline
\end{tabular}

Values are presented as mean \pm SD. Values with different superscript within the same row are significantly different $(\mathrm{P}<0.05)$. $\mathrm{T}$ : control, T1: 35\% sugar was replaced by maple syrup, T2: 70\%sugar was replaced by maple syrup, and T3: 100\% sugar was replaced by maple syrup.

Table 4. Effect of maple syrup on melting resistance of replaced sugar sherbet-ice.

\begin{tabular}{ccccc}
\hline Melting resistance & $\mathrm{T}$ & $\mathrm{T} 1$ & $\mathrm{~T} 2$ & $\mathrm{~T} 3$ \\
\hline $30 \mathrm{~min}$ & $5.63 \pm 0.57^{\mathrm{j}}$ & $6.3 \pm 0.1^{\mathrm{i}}$ & $6.32 \pm 0.01^{\mathrm{i}}$ & $7.03 \pm 0.15^{\mathrm{h}}$ \\
$60 \mathrm{~min}$ & $30.10 \pm 0.1^{\mathrm{g}}$ & $39.367 \pm 0.15^{\mathrm{f}}$ & $40.2 \pm 0.36^{\mathrm{e}}$ & $40.8 \pm 0.52^{\mathrm{d}}$ \\
$90 \mathrm{~min}$ & $80.8 \pm 0.1^{\mathrm{c}}$ & $89.43 \pm 0.37^{\mathrm{b}}$ & $89.733 \pm 0.15^{\mathrm{b}}$ & $91.633 \pm 0.98^{\mathrm{a}}$ \\
\hline
\end{tabular}

Values are presented as mean \pm SD. Values with different superscript within the same row are significantly different $(\mathrm{P}<0.05)$. $\mathrm{T}$ : control, T1: 35\% sugar was replaced by maple syrup, T2: 70\%sugar was replaced by maple syrup, and T3: 100\% sugar was replaced by maple syrup. 
Table 5. Sensory evaluation of replacing sugar by maple syrup sherbet ice

\begin{tabular}{ccccc}
\hline Sensory evaluation & $\mathrm{T}$ & $\mathrm{T} 1$ & $\mathrm{~T} 2$ & $\mathrm{~T} 3$ \\
\hline Flavour 50 & $33 \pm 1.52^{\mathrm{d}}$ & $44 \pm 0.75^{\mathrm{c}}$ & $46 \pm 0.75^{\mathrm{ab}}$ & $47 \pm 0.57^{\mathrm{a}}$ \\
Textures 30 & $24 \pm 0.57^{\mathrm{c}}$ & $24 \pm 1^{\mathrm{c}}$ & $25 \pm 0.75^{\mathrm{b}}$ & $27 \pm 0.57^{\mathrm{a}}$ \\
Colour 10 & $4 \pm 0.57^{\mathrm{c}}$ & $6 \pm 0.57^{\mathrm{b}}$ & $6 \pm 0.75^{\mathrm{b}}$ & $9 \pm 0.57^{\mathrm{a}}$ \\
Appearance 10 & $5 \pm 0.57^{\mathrm{c}}$ & $8 \pm 0.57^{\mathrm{b}}$ & $8 \pm 0.75^{\mathrm{b}}$ & $9 \pm 0.75^{\mathrm{a}}$ \\
\hline
\end{tabular}

Values are presented as mean $\pm \mathrm{SD}$. Values with different superscript within the same row are significantly different $(\mathrm{P}<0.05)$. $\mathrm{T}$ : control, T1: $35 \%$ sugar was replaced by maple syrup, T2: 70\%sugar was replaced by maple syrup, and T3: 100\% sugar was replaced by maple syrup.

of sherbet ice was proportional $(\mathrm{p}<0.05)$ to the amount of maple syrup used. The melting resistance of sherbet ice was expressed as the loss in weight per cent of the initial weight of the tested formula within $90 \mathrm{~min}$. The control treatment showed higher melting resistance than the rest made with the replacement of sugar. It was found that the melting resistance was related to the viscosity of the mix. These results are following those of El-Kholy (2005) and Salama et al. (2016). This may be due to their lower content of water holding constituents (Hassan, 2005). Generally, as the mix viscosity increased the resistance of ice milk to melting increase (Arbuckle, 1986; Salem et al., 2003).

\subsection{Sensory evaluation}

Table 5 represents the sensory evaluation of the final product. The results obtained revealed that the replacement of sugar by maple syrup improved the taste body, texture, colour and overall liking scores significantly $(\mathrm{p}<0.05)$, with maple syrup percentage while the control treatment was less liked due to the whey sour taste.

\section{Conclusion}

Iced drinks with high nutritional value, good physical and organoleptic properties can be successfully prepared by using whey and replacing sugar with maple syrup. The obtained products can be considered functional ice milk varieties.

\section{Acknowledgements}

Thanks to all the staff of the Dairy Lab, Food Science Department, the University of Mosul for their financial support.

\section{References}

AOAC. (2012). Official Methods of Analysis $18^{\text {th }}$ ed. Association of Official Analytical Chemists International. Arlington, Virginia, USA: AOAC.

Aider, M., de Halleux, D. and Belkacemi, K. (2007). Production of granulated sugar from maple syrup with high content of inverted sugar. Journal of Food Engineering, 80(3), 791-797. https:// doi.org/10.1016/j.jfoodeng.2006.07.008

Arbuckle, W.S. (1986). Development of the ice cream industry. In Ice Cream, p. 1-8. Boston, USA: Springer. https://doi.org/10.1007/978-1-4615-7222$0 \_1$

Božanić, R., Barukčić, I. and Lisak, K. (2014). Possibilities of whey utilisation. Austin Journal of Nutrition and Food Sciences, 2, 7.

Chandrapala, J., Duke, M.C., Gray, S.R., Weeks, M., Palmer, M. and Vasiljevic, T. (2016). Nanofiltration and nano-diafiltration of acid whey as a function of $\mathrm{pH}$ and temperature. Separation and Purification Technology, 160, 18-27. https://doi.org/10.1016/ j.seppur.2015.12.046

Chatzipaschali, A.A. and Stamatis, A.G. (2012). Biotechnological utilization with a focus on anaerobic treatment of cheese whey: Current status and prospects. Energies, 5(12), 3492-3525. https:// doi.org/10.3390/en5093492

Chavan, D.S., Lokhande, S.M., Patange, D.D., Ranveer, R.C. and Sahoo, A.K. (2020). Utilization of Dairy By-product for the Development of Whey Ice Candy. European Journal of Nutrition and Food Safety, 12(5), 48-59. https://doi.org/10.9734/ ejnfs/2020/v12i530227

Doultani, S., Turhan, K.N. and Etzel, M.R. (2003). Whey protein isolate and glycomacropeptide recovery from whey using ion exchange chromatography. Journal of Food Science, 68(4), 1389-1395. https:// doi.org/10.1111/j.1365-2621.2003.tb09655.x

El-Kholy, A.M. (2005). Some physical, rheological and sensory properties of ice milk containing rolled oats. Journal of Agriculture Sciences Mansoura University, 30(5), 2639-2650.

Evdokimov, I.A., Volodin, D.N., Misyura, V.A., Zolotoreva, M.S. and Shramko, M.I. (2015). Functional fermented milk desserts based on acid whey. Foods and Raw Materials, 3(2), 40-48. https://doi.org/10.12737/13116

Farahat, A.M., El-Batawy, O.I. and Alla, E.G.G. (2011). Preparation of functional ice cream fortified with date pulp. Egyptian Journal of Dairy Science, 39(2), 285-291 
Gaber, A., Abd- El Satar, A. and Abdeen, I. (2017). Utilization of Ras Cheese Sweet Whey, Acidic Cheese Whey and Permeate to Improve Baladi Bread Properties. Journal of Food and Dairy Sciences, 8 (11), 449-453. https://doi.org/10.21608/ jfds.2017.38954

Hasan, G.M., Saadi, A.M. and Jassim, M.A. (2020). Study the effect of replacing the skim milk used in making ice cream with some dried fruit. Food Science and Technology (Campinas), 41(4), 29620. https://doi.org/10.1590/fst.29620

Hassan, Z.M.R. (2005). Potential healthy functional ice cream manufacture with pumpkin fruit (Cucurbita pepo). Annals of Agricultural Science (Cairo), 50(1), 161-168.

Laaman, T.R. (Ed.). (2011). Hydrocolloids in food processing. Oxford, United Kingdom: WileyBlackwell. https://doi.org/10.1002/9780813814490

Legault, J., Girard-Lalancette, K., Grenon, C., Dussault, C. and Pichette, A. (2010). Antioxidant activity, inhibition of nitric oxide overproduction, and in vitro antiproliferative effect of maple sap and syrup from Acer saccharum. Journal of Medicinal Food, 13 (2),460-468. https://doi.org/10.1089/jmf.2009.0029

Ling, E.R. (1963). A text book of dairy chemistry, Vol. 2, practical, $3^{\text {rd }}$ ed. London: Chapman and Hall Limited.

Mellado-Mojica, E., Seeram, N.P. and López, M.G. (2016). Comparative analysis of maple syrups and natural sweeteners: Carbohydrates composition and classification (differentiation) by HPAEC-PAD and FTIR spectroscopy-chemometrics. Journal of Food Composition and Analysis, 52, 1-8. https:// doi.org/10.1016/j.jfca.2016.07.001

Mollea, C., Marmo, L. and Bosco, F. (2013). Valorisation of cheese whey, a by-product from the dairy industry. In Mazzalupo, I. (Ed.). Food industry, p. 549-588. InTech Open E-Book. https:// doi.org/10.5772/53159

Nimalaratne, C., Blackburn, J. and Lada, R.R. (2020). A comparative physicochemical analysis of maple (Acer saccharum Marsh) syrup produced in North America with special emphasis on seasonal changes in Nova Scotia maple syrup composition. Journal of Food Composition and Analysis, 92, 103573. https:// doi.org/10.1016/j.jfca.2020.103573

Patel, S. (2015). Functional food relevance of whey protein: A review of recent findings and scopes ahead. Journal of Functional Foods, 19(Part A), 308 -319. https://doi.org/10.1016/j.jff.2015.09.040

Pearson, D. (1996). The chemical analysis of foods. $7^{\text {th }}$ ed., p. 227. Edinburgh: Churchill Livingstone.
Perkins, T.D. and van den Berg, A.K. (2009). Maple syrup-Production, composition, chemistry, and sensory characteristics. Advances in Food and Nutrition Research, 56(8),101-143. https:// doi.org/10.1016/S1043-4526(08)00604-9

Rashid, A. and Thakur, E.S. (2012). Studies on quality parameters of set yoghurt prepared by the addition of honey. International Journal of Scientific and Research Publications, 2(9), 1-10.

Salama, W., Alloush, S.A. and Ragb, W.A. (2016). Effect of substituting sucrose with date syrup concentrate on the quality of soy ice cream. In Journal of American Science, 12(6), 1-6.

Salem, A.S., Abdelsalam, A.M. and El- Shibiny, S. (2003). Preparation of low fat and low sugar functional ice cream varieties. Egyptian Journal of Dairy Science, 31, 399-409.

Salim, R.M. (1986). Ice cream, $1^{\text {st }}$ ed. Iraq: University of Mosul.

Sofjan, R.P. and Hartel, R.W. (2004). Effects of overrun on structural and physical characteristics of ice cream. International Dairy Journal, 14(3), 255-262. https://doi.org/10.1016/j.idairyj.2003.08.005

St-Pierre, P., Pilon, G., Dumais, V., Dion, C., Dubois, M.J., Dubé, P., Desjardins, Y. and Marette, A. (2014). Comparative analysis of maple syrup to other natural sweeteners and evaluation of their metabolic responses in healthy rats. Journal of Functional Foods, 11, 460-471. https:// doi.org/10.1016/j.jff.2014.10.001

Wherry, B., Barbano, D.M. and Drake, M.A. (2019). Use of acid whey protein concentrate as an ingredient in non-fat cup set-style yogurt. Journal of Dairy Science, 102(10), 8768-8784. https:// doi.org/10.3168/jds.2019-16247

Yazdanpanah, S. (2020). Effect of sugar substitution with maple syrup on physicochemical, rheological, microbial and sensory characteristics of ice cream. Food Science and Technology, 17(101), 117130. https://doi.org/10.52547/fsct.17.101.117

Zotta, T., Solieri, L., Iacumin, L., Picozzi, C. and Gullo, M. (2020). Valorization of cheese whey using microbial fermentations. Applied Microbiology and Biotechnology, 104(7), 2749-2764. https:// doi.org/10.1007/s00253-020-10408-2 